\title{
The Italian Actress and the Foundations of Early Modern European Theatre: Performing Female Sexual Identities on the Commedia dell'Arte Stage
}

This article examines the multifaceted significance of the emergence of professional actresses in Italy a century before their arrival on the English stage from the 1560s to the early 1600s, and presents key arguments and examples from my ongoing research project, The Actress, the Fetish, and the Fantasy: Performing Early Modern Female Sexual Identities on the Commedia dell'Arte Stage. ${ }^{1}$ It charts the rise of the commedia dell'arte at the intersections of carnival and the piazza and shows how this early form of commercial entertainment used the phenomenal introduction of female performers to sell not only products but also the theatrical institution itself. The argument suggests that the conflicting contemporary debates which on one hand condemned the use of actresses as mere sexual attractions, and on the other, lavished praise on them for their accomplished performances, encapsulate the inextricable intertwining of this new theatrical art form with its commercial viability. My emphasis here will be on laying out the theoretical framework I use to explore the introduction of the actress as an early form of commodity fetish whose spectacularized body becomes a contested site of meaning.

Existing scholarship makes strong connections between the sixteenth-century Italian and English stages by referencing the influx of Italian dramatic models and theatrical conventions into England. In particular, scholars recognize the important influence of the Italian 'theatregram' of the romantic heroine into Shakespearean comedy. ${ }^{2}$ My study deepens our knowledge of this model by offering close readings of several of Flaminio Scala's scenarios as analogues of Shakespearean plots. ${ }^{3}$ In addition it brings into focus the different erotic effects that occur when female performers are present. In tracing the historical progression of the actress's materialization from her earliest appearance as a sideshow attraction to a revered diva, skilled in playing both female and transvestite page roles, we can see how the actress participates in refashioning her spectacularized status as a sexualized commodity fetish through the transformational possibilities that stage performances offer. A case study of Isabella Andreini's contribution to the development of early modern acting theory and practice emphasizes the place of the actress in shaping early modern European theatre.

Many outstanding mid-twentieth-century Italian theatre scholars have stressed the need to re-evaluate the commedia dell'arte as the complex set of 
socio-economic and aesthetic practices that gave birth to early modern theatre. Following Benedetto Croce's perceptive observation that the commedia dell'arte began as an embryonic industry responsive to the demands of the market, ${ }^{4}$ Ferdinando Taviani, Roberto Tessari and several others have explored its origins as the actors progressed towards creating professional companies. ${ }^{5}$ In essence, commedia dell'arte performers existed along a continuum that included the mountebanks, charlatans, buffoons, zanni, musicians, and other itinerant performers who peddled their wares across the established trade routes running across northern Italian and other European cities. ${ }^{6}$ While over time the outstanding companies of actors would distinguish themselves and establish their professional standards, they remained connected with their lesser counterparts by their need to earn a living.

This dominant presence of mountebanks, beggars, and vagabonds, according to Tessari, provides evidence of the socio-economic upheaval in Italy and the breakdown of the church's medieval system of giving charitable relief, in the face of the burgeoning numbers of vagrant poor. ${ }^{7}$ His insistence that the profile of commedia dell'arte actors would continue to 'confront, mirror and often be indistinguishable' from that of the ciarlatano and cerretano throws light on his belief that they were all part of an important economic and cultural shift. ${ }^{8}$ The love affair that the populace developed with these fascinating purveyors of esoteric learning, secret potions, magical cures, and garish entertainment, Tessari proposes, exposed the loss of faith in traditional religion, in the giving of alms and other forms of charity, in the hope for salvation based on good works and the mortification of the flesh. What the popularity of the mountebanks represented for Tessari is a major shift in what people valued as a source of happiness as the marketplace and the consumer satisfaction that comes from the buying and selling of goods and services became the main focus of people's lives.?

Pleasurable activities in the marketplace were also intricately interwoven with the carnival season. While it is not clear how carnival, a specific preLenten calendrical feast in which plays were commonly performed, came to be extended to include the three months between Epiphany and Lent, such a change meant that these itinerant performers could earn their livelihood on the circuit. The English traveller Fynes Moryson notes that, in the 1590s in Italy, 'In the tyme of Carnauall all Cittyes vse to haue publike Comedies acted by Cittizens', and goes on to comment in the same passage, 'Also not only in Carnauall but all the yeare long, all the Markett places of great Cittyes are full of Montebankes, or Ciarlatanes, who stand vpon tables like stages, and to 
sell their oyles, waters, and salues, drawe the people about them by musicke and pleasant discourse like Comedies, hauing a woman and a masked foole to acte these partes with them. ${ }^{10}$ Although the exact relationship between carnival celebrations and the emergent forms of popular entertainment remains uncertain, the iconographic evidence of a 1560 woodcut depicting a group of arte actors supporting a float bearing a huge effigy of Carnival in a triumphant procession, suggests to M.A. Katritzky that 'there was a constant give and take between it [the commedia dell'arte] and the popular sources from which it drew its strength'. ${ }^{11}$ Over time, as new economic arrangements prevailed, the connections between calendrical festivals and marketplace entertainment became less and less fixed, and street performers, acrobats, rope-walkers, charlatans and mountebanks, and commedia dell'arte troupes could be found on the marketplace circuit throughout the entire year. ${ }^{12}$

A strong indication of the Counter-Reformation church's awareness of the powerful draw of marketplace entertainments is evident in the extensive documentation of its condemnations of these extended carnival festivities. Armed with the comprehensive set of rules, the Professio fidei Tridentina, drawn up at the Council of Trent (1545-1563), the church devoted itself to enforcing a new repressive orthodoxy over its parishioners in an effort to reclaim control over their moral, spiritual, and intellectual lives. ${ }^{13}$ With every effort devoted to encouraging its membership to be vigilant in avoiding the temptations of illicit earthly pleasures, the church tried to outlaw ludic carnival celebrations as remnants of ancient diabolical rituals. In 1571, one of the most zealous Tridentines, Carlo Borromeo, requested that the Spanish papal annunciate procure a provision for him which would assist him greatly in 'removing the serious offences committed against God in Carnival time'. $\mathrm{He}$ added that not only religious but also civil authorities in many places have already 'prohibited comedies, jousts, and similar spectacles on feast days under strict penalties not only for those who authorize them, but also for the spectators' ${ }^{14}$ The additional complication of the extension of the original period of Carnival, which meant that the public were no longer observing the high holidays prescribed by the liturgical calendar, led Carlo Bascapè, the Bishop of Novara, to preach on the need to eliminate Carnival altogether in order to make the whole seventy days before Easter into a period of abstinence. Referring to Settuagesima as the seventy days marking the seventy years of Babylonian captivity, he labelled Carnival a return to the pre-salvation period when the devil was in charge. ${ }^{15}$ 
Theatre spectacles in particular came to be singled out as the most pernicious of all carnival activities, because they were regarded as symbolic expressions of the 'World of the Flesh', and hence as being in the service of the devil. In his 1578 letter to Cardinal Paleotti, Archbishop of Bologna, Borromeo emphasized the particularly dangerous threat posed by theatrical representations at Carnival:

indeed, I judge [dramatic performances] to be more dangerous to customs and to souls than those other seedbeds of much evil, the balls, feasts, and such spectacles, because the dishonest and wanton nature of the words, actions, and gestures presented in such dramas, being more latent, make a more vivid imprint on men's souls, and it seems to me, that there might be still more damage from them that could result to that city. ${ }^{16}$

However, try as they might to demonize the theatre with accusations of witchcraft and necromancy, the anti-theatricalists were hard put to prove that the actors were committing idolatry in the traditional sense of the religious worship of a false god.

In their inability to categorize this new theatrical phenomenon, the antitheatricalists' debates reveal the presence of the four conditions cited as necessary indicators that an object is being fetishized, in William Pietz's brilliant investigation of the etymology of 'fetisso'. ${ }^{17}$ This Portuguese word came into use in the sixteenth century when Portuguese traders encountered the very different values that West African societies attached to the objects they were attempting to exchange with them. In a series of three articles, Pietz traces the history of the fetish in modern Western society, establishing it as a vitally important term for understanding the cross-cultural spaces that it opens up across religious, commercial, sexual, and aesthetic practices. His recognition 'that the emergence of a distinct notion of the fetish marks a breakdown in the adequacy of earlier discourse under quite specific historical conditions' alerts us to the importance of recognizing how the fetish signaled a major cultural shift in the modern world, and he notes that the fetish is

recognizable as a discrete thing (a res) because of its status as a significant object within the value codes proper to the productive and ideological systems of a given society. This reified, territorialized historical object is also 'personalized' in the sense that beyond its status as a significant object it evokes an intensely personal response from individuals. This intense relationship to the individual's experience 
of his or her own living self through an impassioned response to the fetish object is always incommensurable with (whether in a way that reinforces or undercuts) the social value codes within which the fetish holds the status of a material signifier. It is in these 'disavowals' and 'perspectives of flight' whose possibility is opened in the clash of this incommensurable difference that the fetish might be identified as the site of both the formation and the revelation of ideology and value-consciousness. ${ }^{18}$

Thus the singular event during which the charlatan first introduced some kind of theatrical entertainment as part of his repertoire in the piazzas during carnival, created in the public a 'meaningful fixation ... [of] a "historical" object, the enduring material form and force of an unrepeatable event'. Next, theatrical performances became 'territorialized in material space' on trestle stages in the marketplace, where they acquired notoriety as 'significant objects within the value codes proper to the productive and ideological systems of a given society'. That this 'reified, territorialized historical object ... evokes an intensely personal response from individuals' is palpably evident in the impassioned rhetoric of the anti-theatricalists and in their commentary of the effects that such performances had on audience members. In their 'disavowals' of the theatre as beyond the pale of the Christian city, labelling its actors 'masters of iniquity', their performances as enticements to commit evil, and their spectators as eternally damned, they reveal a 'clash of ... incommensurable difference' between their puritanical Christian values and those of the new secular marketplace. ${ }^{19}$

The church's fetishization of the theatre as demonically immoral reveals its fear that, if the theatre were to achieve legitimization as a public institution, it might sway the public imagination in directions the church could not control. The church's intense reactions reveal the theatre as a 'site of both the formation and the revelation of ideology and value-consciousness' and often disclose a profound understanding of the many devious ways in which theatrical representations might infiltrate the public imagination. Domenico Gori repeatedly reveals his obsessive interest in the sexually explicit scenes found in contemporary comedies:

We certainly read in Plautus and Terence many of these comedies that are recited in these times, but in which of them have we ever heard (granted that their immodesty may seem too much for us) that on a stage a man and a woman might present themselves wrapped around in a sheet? Who dared among the ancients 
to have Europa appear completely naked? When was it ever permitted in ancient times that a woman might enter the stage and under her garments conceal a man? And yet all these indignities have been seen in the past year in the theatres of Florence. $^{20}$

As this typical commentary indicates, the anti-theatricalists were particularly obsessed with graphic representations of sexual acts performed by actual female bodies. The demonic fascination with the theatre became focalized on female performers, especially since their appearance on the public stage violated church doctrine. Since women have had restricted access to the public sphere throughout history, female performers, no matter what their status, remained emblematic of everything that church officials feared about the ability of the theatre to undermine hegemonic Roman Catholic values. The phenomenal change that their stage appearance signifies probably occurred as a result of the severe economic and social upheaval that left many women without other means to earn a livelihood. The Jesuit theatre reformer, G.D. Ottonelli notes:

Actresses, except for the bench or the stage, are normally limited to the toil of the needle and the distaff, and endure a life of suffering, earning their bread by daily sweat and with great difficulty. But when they join the companies they have a better and safer situation; they are honoured and cherished; and they can claim the esteemed title of Signora. ${ }^{21}$

If the need to earn a living drove women to the stage, then a connection with prostitution seems likely, all the more so because unmarried women had little public status. Because of the marginal itinerant lifestyle, however, even actresses who were married, often to company members, were suspect, since their first obligation was to bring in money. The first record in Italy of a theatrical contract naming a woman, Donna Lucrezia of Siena, signed in Rome in 1564, enlisted her services for the upcoming carnival to perform plays in a company of six men. This date is consistent with the traditional date of entry of women onto the public stage, 1560. Ferdinando Taviani and Mirella Schino cite details from this contract to support their belief that the actresses probably arrived in the profession from the class of honest courtesans (cortegiani oneste) being forced from Rome after the Council of Trent. They claim that Lucrezia's designation of domina, the fact that the contract was signed at 
her house in the campo Marzio, and her lack of a surname in the style of the great courtesans, indicate her probable occupation. ${ }^{22}$

An indication that actresses had little choice in signing contracts geared to the financial needs of their employers can be deduced from a document that precedes that of Donna Lucrezia by two decades. The contract signed at Bourges in 1545 between Marie Ferré, the wife of a street entertainer, and Antoine del'Esperonnière's troupe offers proof of a well-defined repertoire. Ferré was to perform in ancient Roman comedies, other historical dramas, morality plays, farces, and acrobatic tricks in a manner pleasing to the public, in exchange for board and lodging and twelve francs a year. Any gifts from admirers were to be split with Gaillarde, the wife of del'Esperonnière. ${ }^{23}$ The final clause of the contract clarifies that Ferrés value as a performer binds her to her employer rather than her husband, since it seems that extra entertainment will be required to bring in the 'gifts' that she is to share with his wife.

The 1545 contract may point to a much earlier female presence on the travelling circuit of acrobats, rope walkers, musicians, and players. Antonio Grazzini's carnival song of 1552, 'Canto di Zanni e di Magnifici', invites the public to attend a travelling mountebank show with 'Other notable players/ Lovers, Ladies, Hermits and Soldiers / Remain on guard at the hall'. ${ }^{24}$ When the friar Tommaso Garzoni wrote his scathing commentaries on the lower sort of strolling players in 1585 , he derides a newer marketing device, a female transvestite leading the parade:

When these enter a city, immediately a drum makes it known that the gentlemen players have arrived. The Signora, dressed as a man and with sword in hand, advances to survey the field, inviting the public to a comedy or a tragedy or a pastoral, in a palace or at the Pilgrim Inn, to which the mob, by nature eager for novelties and curiosities, immediately rushes to get seats and, paying its entrance money, enters the hall that has been prepared. ${ }^{25}$

Garzoni also gives an unforgettable portrayal of a vast assortment of mountebanks, charlatans, ciurmatori, buffoons, gathered in St. Mark's Square in Venice, offering every imaginable side-show act as they competed for the fickle crowds. The brief moment in which the Tuscan appears with his 'tumbling whore' captures the bizarreness of her act and her irresistible sexual appeal:

Shortly afterwards the Tuscan burst forth through the curtains and mounts the platform with his whore. ... The crowd closes around him, transfixed on the spot, 
all eyes and ears. And behold, in a stroke, he begins some ridiculous story in the Florentine tongue, during which the girl draws her circle on the platform, splays out her arms and legs to pick up the ring outside the circle, and then removing a coin from two crossed swords while sprawled out backwards, whetted a strange desire in the crowd with her lascivious grace. ${ }^{26}$

This same 'lascivious grace' may explain why a Signora Angela was commended by the ducal secretary Luigi Rogna, as 'the one who leaps so well' during the summer of 1567, when she performed with Flaminia and Pantalone's company in Mantua. ${ }^{27}$ The popularity of acrobatic female performers who could both sing and dance is evidenced by the example of a certain cantimbanca, La Vettoria, who 'dressed like a trim and neat boy, packs in large crowds with her dangerous leaps, her divine dancing, her sweet singing, and her beautiful gaze'. According to Avvisi of April and May 1616 in Florence, she had to be protected from the 'dirty old men who keep gazing at her with their mouths open' and escorted home every night by four policemen in order to escape being crushed by the crowds who tried to follow her. ${ }^{28}$

Ottonelli's great compendium of early seventeenth-century performances discusses the irresistible power of the saltatrice to enhance a performance, whether on the bench or stage. Referencing several famous incidents involving female transvestite rope walkers and acrobats, his attention to the details of their movements captures as it condemns their mysterious 'lascivious grace':

What an unseemly sight it offers to the eyes of the viewers, when these little females, to leap more quickly and make many marvellously beautiful turns, appear on the bench or stage dressed in men's clothing, in a lewd farce; and arching, extending and vibrating their bodies with filthy and extravagant gestures and postures, give rise to a thousand libidinous thoughts in the minds of the weak, and show, by thus deforming their own bodies, the far greater deformity of their souls. ${ }^{29}$

Despite the protestations of the great diva Isabella Andreini against the mountebanks, the actresses were never too far apart from their saltimbanche and musical cantimbanche counterparts. Katritzky answers her own question 'Was commedia dell'arte performed by mountebanks?' in the positive by citing iconographic evidence that shows the extensive theatrical activities of the mountebanks. ${ }^{30}$ Her evidence, based on numerous depictions recorded in alba amicorum, pocket-sized volumes compiled by travelling German stu- 
dents, also reveals the presence of the cantimbanca as a regular feature on the mountebank stage. To reveal the close relationship between mountebanks and actors, she follows the German traveller Thomas Platter's journal entries, describing his reactions to performances offered over several weeks by a certain mountebank Zan Bragetta and six companions, at Avignon during the winter of $1598 .{ }^{31}$ Conflating evidence, she suggests that in the earliest pictures, as in Platter's description of Bragetta, Zanni himself is the salesman, with a male or female violin-playing companion'. After 1580, she notes, 'Zanni is accompanied by the salesman, and often also by a woman', ${ }^{32}$ usually depicted in an elegant gown and high-necked ruff, often playing an instrument, and typically flirting suggestively with the zanni. Katritzky's accompanying plates support her argument that the woman becomes a fixture on the mountebank stage, offering her presence to help sell the products and to engage in some level of erotic performance (see figures 1, 2, 3). In fact, Platter's description of Zanni Bragetta's troupe of five men and two women, who appear 'all costumed and neatly masked', attests to their highly accomplished performances in full-length arte style comedies and pastorals, augmented with music, singing, dancing, mime, and acrobatics as part of their routine. ${ }^{33}$ During a typical performance:

They set up a long table in the market place ... and placed a large locked chest next to them on the table. And when they had played an amusing comedy on that same table ... then Zanni, who was their leader, unlocked the chest, and one of his companions, who stood next to him in the costume of a medical doctor, asked him what sort of wares he had in there. ${ }^{34}$

As Katritzky outlines it, Platter's description relates how the Zanni, with the help of all the costumed actors, pitches the miraculous qualities of a precious unguent, which he eventually agrees to sell at an incredibly reduced price. The sale is then carried out by having the buyers throw their handkerchiefs at the actors, with the coin knotted inside. In returning the handkerchiefs to the audience members with the little tin of unguent inside, Platter cynically notes, the female mountebanks also take the opportunity to supplement their earnings: 'They took out the steuben and knotted the little tin into it, throwing everyone back their own handkerchief again, and sometimes, when the women thought it appropriate, they added a little note to the tin, detailing where they could be met, and at what hour, and thus many such practices are combined on the side. ${ }^{35}$ 


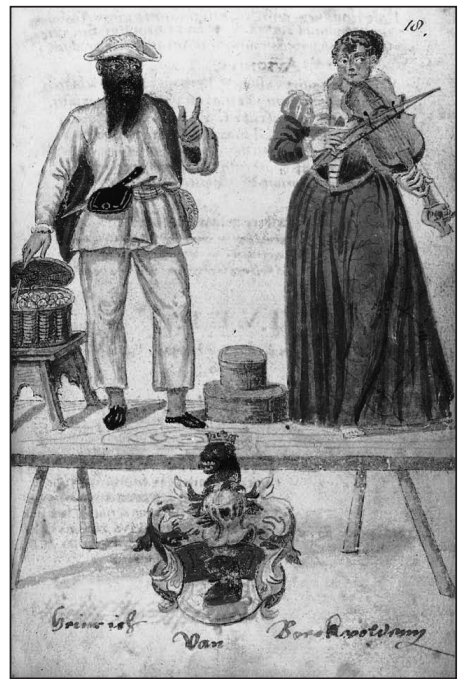

Fig. 1. Two Mountebanks on a Trestle Stage, album amicorum of Sigmundus Ortelius (dated 20 March 1574), British Library Board. All Rights Reserved. MS.Eg.1191, f.18r.

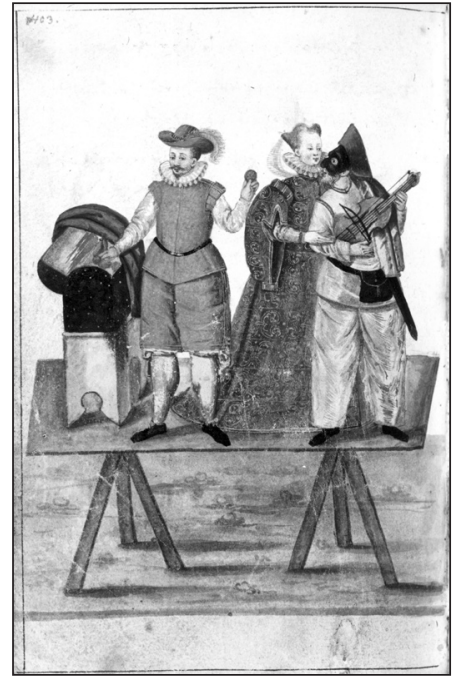

Fig. 2. Three Mountebanks on a Trestle Stage, album amicorum of M.A. Pribil (1587-94), 79.A.3, f.403v. Kupferstichkabinett, Staatliche Museen zu Berlin, Preussischer Kulturbesitz 


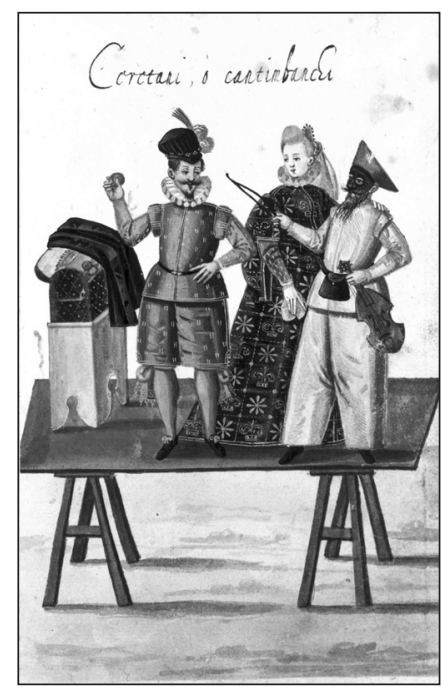

Fig. 3. Ceretani, o cantimbanchi, a sheet from a sketch book of Italian costumes, 79.C.28, fol.21r (1594-5). Kupferstichkabinett, Staatliche Museen zu Berlin, Preussischer Kulturbesitz

As we see in figure 4, this custom of throwing handkerchiefs with money in the air to pay for merchandise could also be the occasion for increasing the charlatans' sales, especially with women present on the trestle. Fynes Moryson describes a similar selling technique, ${ }^{36}$ and Ottonelli is even more to the point in claiming that the woman is particularly good for 'sporte'. Here he answers his own query, 'In what way does the common actress help the earnings of the actors or charlatans?':

1. Because some who would not [otherwise] buy the charlatan's nostrum [literally, secret], do so thanks to the woman. And to what end? In order to throw a handkerchief at her with money in it - throwing it with the intention of hitting her face or breast, and then to receive it back later from her hands with a thousand crude and improper thoughts, indifferent to the quality of the secret [itself], whether it be good or bad. ${ }^{37}$

If, as already noted, the commercial theatre, from the mountebanks to the professional troupes, owed its unprecedented success to creating a mass market through the sensational packaging of its goods and services, its secret weapon proved to be the addition of female performers. While my treatment of Pietz' problematizing of the fetish has concentrated so far on the 


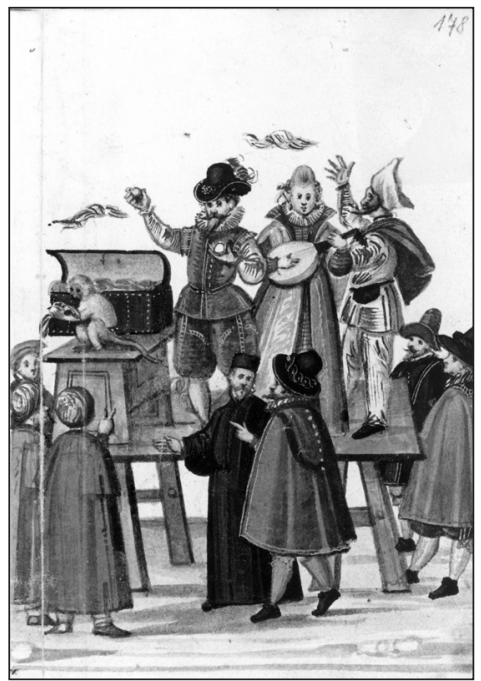

Fig. 4. Three Mountebanks and a Monkey on a Trestle Stage Surrounded by Seven Spectators, album amicorum of Erhard Grünthaler (1591-1612), S.n.13.244,ff.177v-178r . Österreichische Nationalbibliothek, Vienna.

church's attempt to maintain its cultural dominance, by attacking the theatre for its immoral representations of illicit sexual activities, church condemnation also extended to the commercial practices that enabled the theatre to survive. Ottonelli's detailing of how the woman on the trestle stage is used to sell the charlatan's 'secret' thus reveals the symbolic displacement of the value of the product onto an embodied self. This displacement exhibits the exact conditions which produce the commodity fetish. Pietz discusses Marx's explanation of fetishism - the commodity-form ... is nothing but the determined social relations between humans themselves which assumes here, for them, the phantasmagoric form of a relation between things ${ }^{38}$ — as offering 'a phenomenological model of the sort of dialectical process that, for Marx, produces capitalism, in particular, and historically arising social formations in general'. ${ }^{39}$ As Pietz notes:

When a given type of useful thing comes to function as a general-equivalent exchange object in trade activities, it comes to be recognized as embodying a new quality: that of a general form, the very medium of exchange (money). This historically emerging general form expresses, in its being as a material object, the exchange relation that produced it: it is this relation realized as a sensuous object. ${ }^{40}$ 
An excellent example of early consumer capitalism at work, the 'secret' potion has been made so irresistible to audience members that they are willing to exchange coin for it, according it an abstract value which mystifies its real properties and labour costs. In this case, however, reluctant buyers, who may not have experienced sufficient desire on hearing the sales pitch, have an additional opportunity to directly experience the product's qualities 'as a sensuous object' by throwing their coins at the face and breasts of the woman assisting in the sale, since this physical action may, as Ottonelli notes, give them an even greater sexual thrill than that promised by the 'secret' itself. And since the mountebank's assistants, as Platter comments, might on occasion include a note offering themselves in addition to the potion, they also enter into the symbolic exchange relationship. As Pietz continues

Money's reversibility (its ability to be the thing exchanged away or the thing exchanged for) allows the differentiation of the act of exchange into two separate acts: buying a thing for money and selling a thing for money... . The magical moment of fetish formation in this process is the transition of the general form into a universal form, its modal shift from existence and possibility to necessity the mysterious transubstantiation of common social practices into custom or law sanctioned by the community as a whole. ${ }^{41}$

The woman on the trestle, whose sexual desirability and commercial exchangeability are conflated, thus participates in 'this magical moment of fetish formation' when she becomes a universalized object of desire for her audiences. As Ottonelli continues to build his case, she may also sell the products directly to increase sales:

2. The woman earns money on the trestle because sometimes she acts as a saleswoman, offering certain fine commodities, whether perfume, or soap, or lozenges or such similar things, which are pretty and appealing; and there is no danger of her not getting rid of them quickly and successfully, for many vain and lascivious men rush to play the part of customer. ${ }^{42}$

In this instance, she is using her exchangeability with the products to stand in for them both spatially and temporally, trading on her universal desirability to carry out the exchange with her male customers.

Finally, in Ottonelli's third instance, she becomes interchangeable with her performability: 
3. The woman earns money on the trestle too because she pleases by singing and playing an instrument; moreover she often entertains the crowd with various physical and captivating games, after which a cup is circulated among the spectators to solicit a tip for the lady; nor are many slow to give it. Further, as Beltrame noted, because beautiful actresses are often praised, flattered, and occasionally courted by people of rank, and are virtually raped with presents, great monetary gain undoubtedly accrues to many of them. ${ }^{43}$

Now the actress on the trestle and the stage is exchanging her artistry as a musician, singer, dancer, acrobat, raconteur, mime and rhetorician for money. On the trestle, it may involve the direct exchange of paying money for the show, after experiencing the performance. On the stage, once the great actresses had established their reputations, the performances themselves are eclipsed by the diva worship that made them into iconic symbols of their profession. Indeed, as the church continued to protest against the theatre's legitimacy as a valid art form throughout the seventeenth century, the debates increasingly centred on the connections between the diabolic presence of the actress, and the mercenary nature of the commedia dell'arte. As a contested site of meaning, the actress is accused by Ottonelli and others of causing more harm to society than the prostitute, because of her power to enchant a large public through her acting skills and hence to damage the souls of men, rather than just attending to the private needs of their bodies as prostitutes did. ${ }^{44}$ If the above argument reveals the church's reluctant recognition that the seductive charms of the actress could not be disavowed, the theatre apologists who came to her defence were quick to fetishize her as the sublime embodiment of the aesthetic, moral, and spiritual value of their art. As the diva Isabella Andreini's equally famous actor-author son, Giovan Battista Andreini, wrote in his theatrical treatise La Ferza (The Scourge), in 1625:

If the commedia is full of marvel and if admirability is a precept of this so rare dramatic poem, why should we deprive it of the greater marvel that it is to hear the astonishing wonder-working speaking woman in the theatre? ... Don't you see that [in removing women from the stage] you take from us the verisimilar, the soul and heart of this poem, and every grace, and every affect, hindering the theatre with this defect? 45

Andreini's plea was answered in that it proved impossible to eradicate the actress from the stage. Present as 'divinized emblem', produced by 'a new 
purposive desire', the actress was also positioned to look for ways in which the desire expressed for her as a sexual and cultural commodity could be actively reciprocated and reclaimed by her, both in her onstage performances and in her offstage existence. ${ }^{46}$

Rosalind KerR

\section{Notes}

1 Funded by a Social Sciences and Humanities Research Council of Canada grant. Graduate student involvement includes the work-shopping of Flaminio Scala's The False Husband.

2 See Robert Henke's article in this journal

3 Flaminio Scala, Il teatro delle favole rappresentative, 2 vols, Ferruccio Marotti (ed.) (Venice 1611, Milan, 1976).

4 Benedetto Croce, 'Intorno alla "Commedia dell'Arte", Poesia popolare e poesia d'arte (1932 Bari, 1957), 507-9, in Ferdinando Taviani and Mirella Schino, Il segreto della Commedia dell'Arte (Florence, 1982), 203-4.

5 Taviani and Schino, Il segreto. Roberto Tessari, La Commedia dell'Arte nel Seicento: 'Industria' e 'Arte giocosa' della civilità barocca (Florence, 1969).

6 Siro Ferrone, 'La vendita del teatro: Tipologie Europee tra Cinque e Seicento', The Commedia dell'Arte from the Renaissance to Dario Fo: The Italian Origins of European Theatre, Christopher Cairns (ed.) (Lewiston, New York, 1988), 35-72.

7 Roberto Tessari, Commedia dell'Arte: la Maschera e l'Ombra (Milan, 1989), 31-47.

8 Ibid, 37.

9 Ibid, 40.

10 Fynes Moryson, Shakespeare's Europe: A Survey of the Condition of Europe at the end of the $16^{\text {th }}$ century, being unpublished chapters of Fynes Moryson's Itinerary (1617), Charles Hughes (ed.) (1903, New York, 1967), 465.

11 M.A. Katritzky, 'Italian Comedians in Renaissance Prints', Print Quarterly 4.3 (September 1987): 246.

12 See M.A. Katritzky, Women, Medicine and Theatre, 1500-1750: Literary Mountebanks and Performing Quacks (Aldershot, 2007), 61-85.

13 Giuliano Procacci, History of the Italian People, trans. Anthony Paul (London, 1970), 187.

14 Carlo Borromeo, Lettera a Mons. Giambattista Castagna, Arcivescovo di Rossano, Nunzio apolostico in Spagna, (2 novembre, 1571), in Ferdinando Taviani, La Commedia 


\section{I96 Issues IN REVIEW}

dell'Arte e la società barocca: La fascinazione del teatro (Rome, 1969), 18. Unless otherwise indicated, all translations are my own

15 Carlo Bascapè, Della Settuagesima, 1606, in Taviani, La fascinazione, 61.

16 Lettera al Cardinal Gabriello Paleotti, Arcivescovo di Bologno (luglio 1578), in Taviani, La fascinazione, 23.

17 William Pietz, 'The problem of the fetish, I', Res 9 (Spring 1985), 12-13.

18 Ibid, 6, 12.

19 Baldesano, in Taviani, La fascinazione, 99.

20 Domenico Gori, Trattato contro alle commedie lascive (1604), in Taviani, La fascinazione, 141.

21 G.D. Ottonelli, 'Quesito sesto. il gusto delle donne comiche in far quest'arte è ragione di scusa sufficiente per la publica comparsa ?', Capo Terzo del Libro I, detto la Qualità delle Commedie, Della Cristiana Moderazione del Teatro, in Taviani, La fascinazione, 356.

22 Taviani and Schino, Il segreto, 335.

23 M. Boyer, Mémoires de la Société historique du Cher, serie IV, vol, 4, 1888. Qtd. in Léopold Lacour, Les premières actrices françaises (Paris, 1921), 6. See also Virginia Scott, 'La Virtu et la volupté. Models for the Actress in Early Modern Italy and France', Theatre Research International 23.2 (Summer 1998), 152-8.

24 Antonio Grazzini, Canto di Zanni e di Magnifichi in Charles Singleton (ed.), Nuovi canti carnascialeschi (Modena, 1940), 127-8.

25 Tommaso Garzoni, 'De'comici e tragedy così auttori come recitatori, cioè de gli istrioni', La Piazza universale di tutto le professioni del mondo (Venice, 1595), 739-40; trans. Kenneth Richards and Laura Richards, The Commedia dell'Arte: A Documentary History (Oxford, 1990), 70.

26 Garzoni, La Piazza universale, 745-7 (my translation).

27 Alessando D’Ancona, Le origini del teatro italiano (1891, Roma 1971), 2: 449.

28 See Robert Henke, 'The Italian Mountebank and the Commedia dell'Arte,' Theatre Survey 38.2 (November 1997), Document G, 27 (in translation).

29 Ottonelli, 'L'ordinarie comiche nuocono all'anime co' salti fatti nel publico teatro?', in Taviani, La fascinazione, 385.

30 M.A. Katritzky, "Was Commedia dell'Arte Performed by Mountebanks?” Album amicorum Illustrations and Thomas Platter's Description of 1598', Theatre Research International 23.2 (Summer 1998): 104-25 (four of whose accompanying plates are also reproduced in the present article).

31 M.A. Katritzky, "Mountebanks, Mummers and Masqueraders in Thomas Platter's Diary (1595-1600)', The Renaissance Theatre. Texts, Performance, Design, 1: Christopher Cairns (ed.) (Aldershot, 1999), 12-44. See also, Katritzky, Women, 63-85. 
32 Katritzky, 'Was Commedia dell'Arte Preformed by Mountebanks?', 117.

33 Ibid, 117 \& figs.1-3.

34 Ibid, 114 (translation).

35 Ibid, 114 (translation). For an English dramatic treatment, see Ben Jonson, Volpone, in Helen Ostovich (ed.), Ben Jonson: Four Comedies (London, 1997), 2.2, especially 175 SD to the end of the scene, in which Volpone offers a consummate impersonation of the Italian mountebank Scoto so successfully, in his sales pitch of the miraculous cure-all product, that Celia responds by throwing him her knotted handkerchief from the window where she watches. Unfortunately her husband assumes that she is the mountebank's 'Franciscina' (2.3.3, and 2.5.1-44), a type of 'the tumbling whore' (2.6.14), in a series of verbal images that reflect mountebank practices.

36 Moryson, Shakespeare's Europe, 424-5.

37 Ottonelli, 'In che modo l'ordinarie comiche aiutano al guadagno de'comici, o de'ciarlatani?' Capo terzo, Libro I, Detto La Qualità delle Commedie (1648), in Taviani, La fascinazione, 361, trans. Richards and Richards, 245.

38 Karl Marx, Capital: A Critique of Political Economy, vol. 1, trans. Ben Fowkes (New York, 1977), 165.

39 William Pietz, 'Fetishism and Materialism: The Limits of Theory in Marx,' Fetishism as Cultural Discourse, Emily Apter and William Pietz (ed.), (Ithaca and London, 1993), 119-51.

40 Ibid, 146.

41 Ibid, 146-7.

42 Ottonelli, 'In che modo?', in Taviani, La fascinazione, 361, trans. Richards and Richards, 245.

43 Trans. Richards and Richards, 245.

44 Ottonelli, 'Se si permettono le meretrici, non si possono anche permettere i mercenarii comedianti ?' ('If prostitutes are legal, couldn't we also accept the commercial actresses?') , in Taviani, La fascinazione, 441-3.

45 Giovan Battista Andreini, La Ferza, Contro l'accuse date alla commedia in Ferruccio Marotti and Giovanni Romei, La Commedia dell'Arte e la società barocca: La Professione del teatro (Rome, 1991), 510.

46 Pietz, 'The problem of the fetish, I', 8. 